
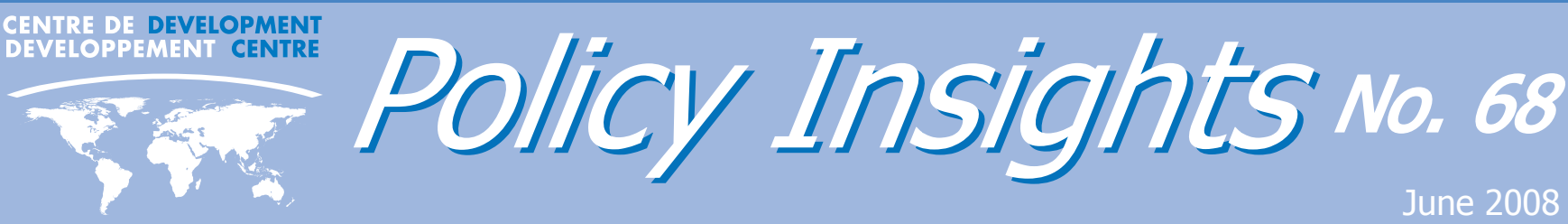

June 2008

\title{
Transition, Globalisation and Labour in the Black Sea Economic Co-operation and Central Asian Regions
}

\section{(based on Black Sea and Central Asia Economic Outlook 2008)}

\author{
by Loukas Balafoutas and Kiichiro Fukasaku
}

- Globalisation has brought benefits to the economies in the Black Sea Economic Co-operation (BSEC) and Central Asia (CA), but compounded volatility and uncertainty associated with the transition to market economy.

- Labour markets have been put under pressure, as BSEC-CA countries compete on the international arena.

- One important form of labour market adjustment has been a large amount of migration flows within the BSEC$\mathrm{CA}$ region and to the neighbouring countries.

\section{Opening up to the Global Economy}

The end of central planning meant that BSEC-CA countries had the opportunity to "open up" and become part of the global economy. The speed and the extent to which they chose to do so was a function of several political, economic, historical, geographical and cultural factors idiosyncratic to each country. Opening up to the global economy has provided new opportunities for trade and migration, but exposure has imposed a harsh discipline on producers with repercussions for the labour market.

The Black Sea and Central Asia Economic Outlook provides an overview of recent economic developments in the 17 countries in the Black Sea Economic Co-operation (BSEC) and Central Asia (CA $)^{1}$. Their experience provides lessons about aspects of their integration in the world economy.

Increased public and private financial inflows, including workers' remittances have come from integration into the world economy, while new participation in international trade has provided the opportunity to exploit their comparative advantage in energy, raw materials, or agricultural exports. Domestic firms can now become more competitive through knowledge and technology transfers. There has been a strong upturn in foreign direct investment (FDI) flows in the BSEC region.

1 The 12 BSEC countries are Albania, Armenia, Azerbaijan, Bulgaria, Georgia, Greece, Moldova, Romania, Russia, Serbia, Turkey and Ukraine; the five CA countries include Kazakhstan, the Kyrgyz Republic, Tajikistan, Turkmenistan and Uzbekistan.
On the downside, volatility and uncertainty in the BSEC-CA economies has increased, primarily through the following channels:

$\diamond$ The economies have become exposed to the volatility of world prices for food, energy and raw materials; most countries in the region rely heavily on exports of energy (Azerbaijan, Kazakhstan, Russia, Turkmenistan) or products such as cotton (Uzbekistan, Tajikistan), gold (the Kyrgyz Republic) or aluminium (Tajikistan). The import prices for a wide range of products (including energy) are also of particular concern for every country.

$\diamond$ Vulnerability is enhanced by the fact that global financial markets are increasingly linked, so that crises tend to spread and are particularly harmful to less resilient economies, as we saw during the 1998 Russian financial crisis.

$\diamond$ Unskilled workers are becoming increasingly vulnerable in the labour market².

\section{The Impact on Work and Well-Being:} Employment and Migration

The most immediate impact of the double shock of transition and globalisation on labour markets was the rise in unemployment. Many firms were not competitive enough to resist import competition from foreign firms, let alone

2. OECD, 2007. 
enter foreign markets. This contributed to a high rate of job destruction, as firms undertook extensive restructuring and struggled to adjust to the new environment and its demands. The loss of jobs was further driven by privatisation and the decline in state subsidies to inefficient enterprises. Job creation tended to lag behind as new firms were slow to emerge or expand in an often unfavourable institutional environment leading to "jobless growth".

This grim picture is shown clearly in Table 1 , which reports the changes in employment since the mid-1990s in the BSEC region; most countries have experienced considerable declines in employment, despite generally positive rates of economic growth. The employment trend seems to be somewhat more positive in those Central Asian countries for which reliable data exist, and evidence suggests substantial increases in the total number of jobs in Kazakhstan (since 2001) and the Kyrgyz Republic.

The lifting of restrictions on movement and the resulting surge in migration has also had a significant impact on BSEC-CA countries. Emigration can help relieve the pressure on labour markets, while remittances provide a vital boost for many economies in the region, often accounting for large shares of household income. The outflow of qualified people (known as "brain drain" in the case of highly skilled workers), however, can be detrimental to current and future productivity, as well as to the demographic structure. Other aspects of adjustment are reviewed in detail in the Black Sea and Central Asia Economic Outlook.

Table 1. Percentage Change in Aggregate Employment in Transition BSEC, 1995-2005

\begin{tabular}{lrlr}
\hline Albania & -18.19 & Moldova & -11.71 \\
Armenia & -25.61 & Romania & -17.98 \\
Azerbaijan & 6.56 & Russia & 6.27 \\
Bulgaria & -0.18 & Serbia & -20.70 \\
Georgia & 0.81 & Ukraine & -14.28 \\
\hline
\end{tabular}

Source: Key Indicators of the Labour Market database, ILO. Labour force survey data for Russia and Ukraine. Reference period: 1995-2005 except Georgia (1998-2005), Moldova (1999-2005) and Serbia (1995-2003).

Further reading:

OECD (2008), Black Sea and Central Asia: Promoting Work and Well-Being, OECD Development Centre, Paris. OECD (2007), Employment Outlook 2007: Addressing the Globalisation Paradox, OECD, Paris.

Readers are encouraged to quote or reproduce material from OECD Development Centre Policy Insights for their own publications. In return, the Development Centre requests due acknowledgement and a copy of the publication. Full text of Policy Insights and more information on the Centre and its work are available on its web site: www.oecd.org/dev

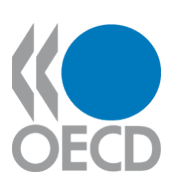

